\title{
The challenges of teaching and learning during a pandemic become an opportunity: reflections on a student and academic partnership.
}

\author{
Giulia Getti, Sarah Harris, Ioana-Christina Alexandru, Raphaelle Boulas, Louise \\ Brempong, Rebekah Huckstepp, Vishwa Hiteshbhai Gandhi, \\ Diana Patricia Muntean, Ana C Pires Piedade, Clara Tresserras-Segura, \\ Adanonso Ugwuanyi \\ School of Science, University of Greenwich, UK
}

\begin{abstract}
The current pandemic has forced us to implement major changes in the way we communicate, interact and work, all of which have had a massive impact upon all aspects of our lives. Academics and students alike have had to adapt very quickly to the new situation and the challenges encountered, although viewed from different perspectives, are largely similar. Changes are often unsettling and taxing, especially when they are not the result of a personal choice, but they can also offer great opportunities, the most significant of which is for lecturers and learners to develop best practice together, in partnership (Kurczek and Johnson, 2014). This article reflects upon how sharing our experience of a students-andstaff partnership at the University of Greenwich 2021 SHIFT conference has affected our experience of teaching and learning during a pandemic.
\end{abstract}

Keywords: Student partnership, on-line learning, confidence, conference, higher education

\section{Background}

This project started from a desire to learn, from students, which of the changes they experienced during the pandemic have improved their learning experience. Our aim was to present our findings at the University of Greenwich SHIFT 2021 conference on teaching and learning so that the students' voice would reach a wider audience. Our working group comprised eleven women: nine students and two lecturers from different ethnic backgrounds and nationalities. All of us, sharing an interest in science, microbiology and the power of diversity in expanding our learning and understanding, contributed equally to the design and the progress of the project. We believe that to look at the same problem from the varying points of view of our diverse cultural backgrounds offers a broader perspective and fuller understanding, with consequently a better learning and teaching experience. We placed strong emphasis upon supporting the collaborative aspect of the project, something often neglected in collaborative learning (Le et al., 2017; Healey et al., 2014).

Close interaction between students and academic staff is well known to be important to the improvement of student learning, development, engagement and satisfaction in higher education (Astin, 1993; Kuh et al., 2005). Nevertheless, interaction between academics and students tends, by and large, to place the student as the receiver of knowledge and the academic as the deliverer of it. That approach has several well-known limitations (Benware and Deci, 1984; Biggs, 1999) and does not recognise that learning does not end when one 
becomes an academic, and that learners are best placed to make academic staff aware of which approaches work best in their education. Moreover, establishing a partnership empowers all students to engage deeply with their education (Scager et al., 2016). The pandemic has imposed such profound changes on the way we do things, it has forced us to leave our comfort zone and inspired us to change our perspective as well brought us closer as a university community.

We have come together at weekly meetings to discuss and reflect on how the current pandemic has impacted our university experiences and to discuss best practice. This led us to share our experiences and the journey that we took with our university. We reflected on and identified best practice; we also inspired each other and supported confidence-building both through discussion and also by presenting our reflections (Getti et al., 2021). Each one of us presented one slide. Here, we share what this partnership has taught us.

\section{Reflections}

There seems to be an invisible wall between academics and learners, which we inherit from the past and do not question. Delivering a collaborative presentation at SHIFT has allowed us all, students and staff, to expose our respective roles to joint scrutiny, reappraise them and adjust in the interests of better learning AND teaching. For our group, this has resulted in that wall coming down.

Traditionally, universities promote collaborative learning between students, but there is little or no collaboration between academic staff and learners - a barrier that contributes to some students' hesitancy about engaging with academics, with the inevitable consequence that academics' understanding and ability to support students' learning fully are limited.

During the pandemic, both students and teachers have faced similar challenges and this project showed us how, by working together and breaking down the wall between us, we can overcome them. The project 'Teaching \& Learning during COVID-19' was a great way for students to build a stronger relationship with lecturers and with peers.

Lack of face-to-face interaction, combined with great changes to delivery of the curriculum, made things extremely difficult: for lecturers, to obtain timely feedback on the degree of success of the changes; for students, to feel listened to. We found that this, in many instances, resulted, for students, in a growing sense of isolation and consequent disengagement and, for staff, in a similar sense of remoteness. Our collaborative experience, however, allowed for the development of stronger connections between fellow student learners and between students and lecturers (themselves learners). It enabled the creation of an online community with no geographical barriers, even when we found ourselves spread across several countries due to lockdowns and restrictions on movement. This helped both sides to overcome the sense of isolation and maintain motivation throughout the academic year.

Working together towards presenting at SHIFT changed our perspective of the University ethos, showing our institution's investment into the culture of learning, not just academically, but also in the holistic development of its students, so encouraging their curiosity and their confident independence of thought during their passage through higher education. 


\section{Conference reflections}

Joining the 'Teaching \& Learning during COVID-19' group started from the desire to feel a sense of community during these unprecedented (and often lonely) times. Presenting our experience at SHIFT made us realise that there is a tremendous power in our voice. Throughout the past months, we have supported one another through difficult times; we have made connections; we have had important discussions about how to better our teaching and learning - not only during the pandemic, but after it, too.

This project has showed us that despite - and sometimes because of - the challenges faced this year, studies have been as valid as they were previously. It has offered an opportunity to usher in new modes of teaching; it has inspired students to take ownership of their learning and lecturers to explore new teaching approaches and learn from the students' experience.

Moreover, the presentation at the SHIFT conference gave students a new-found confidence, not only in their communication and presentation skills, but in their personal capability and value. It allowed learners to realise how much they have grown during their academic experience and encouraged them to make their voice heard by actively participating in group meetings and in sharing ideas. As lecturers, we have been able to reflect on the positive influences that closer collaboration with students can have, not only on their confidence, but also on their academic performance and wellbeing; in addition, we have gained invaluable information about best practice.

As important tools for a successful blended-learning strategy, students identified interactive teaching material, live sessions, continuous assessment, supportive teamwork and enthusiasm in an educator's delivery.

\section{Conclusion}

Our experience reflects the findings by Cook-Sather et al, (2014), that partnerships tend to produce similar outcomes for both students and academic staff. These include enhanced motivation and learning, as well as development of a stronger sense of identity. This project has been an incredibly successful experience, one that we felt fortunate to have participated in and one that we hope to continue. As Breen and Littlejohn (2000) suggest, sometimes the greatest constraint to moving in a new direction comes from the limits of "our own imaginations or assumptions".

\section{Reference list}

Astin, A. (1993) What matters in college? Four Critical years Revisited. San Francisco: Jossey-Bass. ISBN: 978-0-787-90838-6

Benware, C. and Deci, E. (1984) 'Quality of learning with an active versus passive motivational set.' American Educational Research Journal, 21(4), 755-65. Available at: https://doi.org/10.3102/00028312021004755 (Accessed: 08 June 2021). 
Biggs, J. (1999) 'What the student does: teaching for enhanced learning.' Higher Education Research \& Development, 18(1), 57-75. Available at:

https://doi.org/10.1080/0729436990180105 (Accessed: 08 June 2021).

Breen, M.P. and Littlejohn, A. (2000) 'The practicalities of negotiation.' In: Breen, M.P. and Littlejohn, A. (eds.) Classroom decision-making: Negotiation and process syllabuses in practice. Cambridge: Cambridge University Press, 5-38. ISBN: 0-521-66614-7

Cook-Sather, A., Bovill, C. and Felten, P. (2014) Engaging students and partners in teaching and learning: A guide for faculty. San Francisco: Jossey-Bass. ISBN: 978-1-118-43458-1

Getti, G., Harris, S., Hiteshbhani Gandhi, V., Huckstepp. R.L., Pires Piedade, A.C., Tresserras Segura, C., Alexandru, I.C.C., Ugwuanyi, A.O., Boulas, R.H., Muntean, D.P. and Brempong, L.A. (2021) 'Teaching and learning during a pandemic, a challenge and an opportunity.' SHIFT conference presentation, University of Greenwich, $13^{\text {th }}$ January 2021. Abstract booklet available at: https://docs.gre.ac.uk/rep/learning-teaching/shift2021programme (Accessed: 08 June 2021).

Kuh, G.D., Kinzie, J., Schuh, J.H. and Whitt, E.J. (2005) Assessing Conditions to Enhance Educational Effectiveness: The Inventory for Student Engagement and Success. San Francisco: Jossey-Bass. ISBN: 978-0-787-98220-1

Kurczek J. and Johnson J. (2014) 'The student as teacher: Reflections on collaborative learning in a senior seminar.' Journal of Undergraduate Neuroscience Education,12, A93-9.

Le, H. Janssen, J. and Wubbels, T. (2018) 'Collaborative learning practices: teacher and student perceived obstacles to effective student collaboration.' Cambridge Journal of Education, 48(1), 103-122. Available at: https://doi.org/10.1080/0305764X.2016.1259389 (Accessed: 08 June 2021).

Healey, M., Flint, A. and Harrington, K. (2014) Engagement through partnership: students as partners in learning and teaching in higher education. Location: Higher Education Academy. Available at:

https://www.heacademy.ac.uk/sites/default/files/resources/engagement through partnership .pdf (Accessed: 08 June 2021).

Scager, K., Boonstra, J., Peeters, T., Vulperhorst, J. and Weigant, F. (2016) 'Collaborative learning in Higher Education: evoking positive interdependence.'CBE: Life Sciences Education, Winter, 15(4), ar69. Available at: https://doi.org/10.1187/cbe.16-070219 (Accessed: 08 June 2021). 